International Journal of Advanced Academic Research (Sciences, Technology and Engineering) | ISSN: 2488-9849 Vol. 6, Issue 8 (August, 2020) | www.ijaar.org

Journal DOI: 10.46654/ij.24889849

Article DOI: 10.46654/ij.24889849.e6813

\title{
ASSESSMENT OF HEAVY METALS AND PHYTOCHEMICAL COMPOSITION OF PIPER GUINEENSE (THONNING, 1827) LEAVES COLLECTED FROM THREE MARKETS IN LAGOS, NIGERIA
}

\author{
${ }^{1}$ Adu Ayotunde Abosede; ${ }^{2}$ Aderinola Oluwatoyin Joseph; ${ }^{3 *}$ Mekuleyi Gabriel Olarinde \\ and ${ }^{1}$ Uyi Osai James \\ ${ }^{1}$ Department of Botany, Lagos State University, Ojo, Lagos, Nigeria \\ ${ }^{2}$ Department of Zoology and Environmental Biology, Lagos State University, Ojo, Lagos, \\ Nigeria \\ ${ }^{3}$ Department of Fisheries, Lagos State University, Ojo, Lagos, Nigeria \\ *Corresponding author: tosingabriel76@yahoo.com, +2348092740045
}

\begin{abstract}
The study examined the phytochemical composition and heavy metals ( $\mathrm{Cu}, \mathrm{Zn}, \mathrm{As}, \mathrm{Ni}, \mathrm{Pb}, \mathrm{Cd}$, $\mathrm{Cr}$ ) present in Piper guineense from three markets in Lagos, Nigeria. The qualitative and quantitative analyses were carried out on both wet and dry samples using standard procedure. The results revealed the presence of bioactive compounds namely Alkaloids (53.12 \pm 0.14 and $37.66 \pm 0.00 \mathrm{mg} / \mathrm{l00g})$, Tannins $(6.21 \pm 0.13$ and $4.12 \pm 0.00 \mathrm{mg} / \mathrm{lo0g})$, Flavonoids $(67.99 \pm 0.17$ and $23.98 \pm 0.00 \mathrm{mg} / 100 \mathrm{~g})$, Terpenes $(14.63 \pm 0.18$ and $8.95 \pm 0.00 \mathrm{mg} / 100 \mathrm{~g})$, Saponins $(5.99 \pm 0.14$ and $4.76 \pm 0.00 \mathrm{mg} / 100 \mathrm{~g})$, Phenols $(6.02 \pm 0.11$ and $2.97 \pm 0.00 \mathrm{mg} / \mathrm{lo0g})$ for dry and wet samples respectively from $P$. guineense collected from Igando while from Ikotun market the values are: Alkaloids (4.88 \pm 0.00 and $29.87 \pm 0.02 \mathrm{mg} / 100 \mathrm{~g})$, Tannins $(4.44 \pm 0.00$ and $2.97 \pm 0.02$ $\mathrm{mg} / 100 \mathrm{~g})$, Flavonoids $(58.87 \pm 35.36$ and $12.65 \pm 0.01 \mathrm{mg} / 100 \mathrm{~g})$, Terpenes $(6.98 \pm 0.00$ and $4.96 \pm 0.02 \mathrm{mg} / \mathrm{lo0g})$, Saponins $(2.67 \pm 0.00$ and $2.02 \pm 0.01 \mathrm{mg} / 100 \mathrm{~g})$, Phenols $(4.55 \pm 0.00$ and $1.88 \pm 0.02 \mathrm{mg} / 100 \mathrm{~g})$. Egbeda had Alkaloids $(40.43 \pm 18.08$ and 33.21 \pm 0.01$)$, Tannins $(9.06 \pm 4.17$ and 4.08 \pm 0.00$)$, Flavonoids (49.77 \pm 25.60 and $23.88 \pm 0.00)$, Terpenes $(8.86 \pm 8.34$ and $6.16 \pm 0.01$ $\mathrm{mg} / 100 \mathrm{~g})$, Saponins $(3.11 \pm 3.94$ and $2.14 \pm 0.00 \mathrm{mg} / \mathrm{lo0g})$ and Phenols $(5.13 \pm 1.37$ and $3.45 \pm 0.02 \mathrm{mg} / \mathrm{l00g}$ ). Values of phytochemicals (dry and wet weight) were significantly $(p<0.05)$ higher in samples from Igando than samples of other markets. However, there was no significant difference among heavy metals detected in Piper guineense across the three markets. All the metal in the P. guineense were below WHO maximum permissible limit. The findings indicated that $P$. guineense collected from the markets are safe for consumption and good for medicinal use. However, efforts should be made by farmers planting P. guineense and seller of the vegetable to avoid further contamination either through soil or direct exposure to metals compounds.
\end{abstract}

Keywords: P. guineense, Markets, Consumption, Metals, Bioactive compound. 
International Journal of Advanced Academic Research (Sciences, Technology and Engineering) | ISSN: 2488-9849

Journal DOI: 10.46654/ij.24889849

Vol. 6, Issue 8 (August, 2020)| www.ijaar.org

Article DOI: 10.46654/ij.24889849.e6813

\section{Introduction}

Plants are rich sources of bioactive compounds which have many health promoting effects like antioxidant, antibacterial, antihypertensive and anti-inflammatory etc. (Asgarpanah and Haghighat, 2012). Phytochemicals such as terpenoids, phenolic metabolites, tannins and alkaloid are examples of secondary metabolites produced by plants, from which the plants are thought to get their healing properties (Harborne, 1999). According to the World Health Organization, more than $80 \%$ of the world's population relies on traditional medicine for their primary healthcare needs and so it is extremely important to use the most appropriate methods to extract the active components from plant materials (Bennerman and Chen, 1983).

Medicinal plants have been cited as a potential source of heavy metal contamination during cultivation or processing (Adeyolanu et al., 2016). Heavy metals such as lead (Pb), cadmium (Cd) and arsenic (As) have toxic effects on human health. Toxic metals can accumulate persistently in the body over a lifetime. Although, some heavy metals such as $\mathrm{Cu}, \mathrm{Fe}, \mathrm{Mg}, \mathrm{Zn}$ and $\mathrm{Co}$ are essential elements for normal growth, development and metabolism of plant, however, high concentrations of these elements could lead to physiological disorders in plants (Dwivedi and Dey, 2002).

Piper guineense is an evergreen climbing shrub producing woody stems from 4-20 metres tall. The plant supports itself on other plants by means of adventious roots which are produced along the stems. The plant is regionally known as ashanti pepper, Benin pepper, false cubeb, Guinea cubeb and is a popular spice in Africa that are semi- cultivated in countries such as Nigeria where the leaves, known as uziza, are used as a flavouring for stews and also as a medicine (Ruffo et al., 2002). Despite the importance of $P$. guineense leaf, its properties as regards bioactive ingredients and heavy metals concentration has often been neglected. Therefore, the purpose of this study is to assess the contents of phytochemical and heavy metals in $P$. guineense from the selected markets (Igando, Ikotun and Egbeda) in Lagos State, Nigeria.

\section{MATERIALS AND METHOD}

\section{Collection of Samples}

Fresh leaves of Piper guineense (Plate 1) was collected between July and September 2019, from three different markets (Igando, Ikotun and Egbeda) located in Alimosho Local Government Area of Lagos State.

\section{Pre-treatment Methods for Plant Samples}

The leaves of the $P$. guineense were separately detached from the stems and cleaned by gentle washing with distilled water. Thereafter, the samples were separately air-dried, for three days, and then pulverized using pestle and mortar, and then saved for analysis.

\section{Sample Extraction}

$20 \mathrm{~g}$ each of the pulverized leave samples was weighed into labeled sample vials, macerated, and moistened with $100 \mathrm{ml}$ of $70 \%$ methanol. The vials were capped and the mixture was allowed to stand for 24 hours. The extracts were placed on a water-bath at $40^{\circ} \mathrm{C}$ to evaporate the methanol. Thereafter, the residues were saved as crude extracts for phytochemical analysis. 


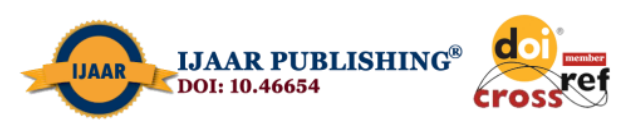

International Journal of Advanced Academic Research (Sciences, Technology and Engineering) | ISSN: 2488-9849

Journal DOI: 10.46654/ij.24889849

Vol. 6, Issue 8 (August, 2020) | www.ijaar.org

Article DOI: 10.46654/ij.24889849.e6813

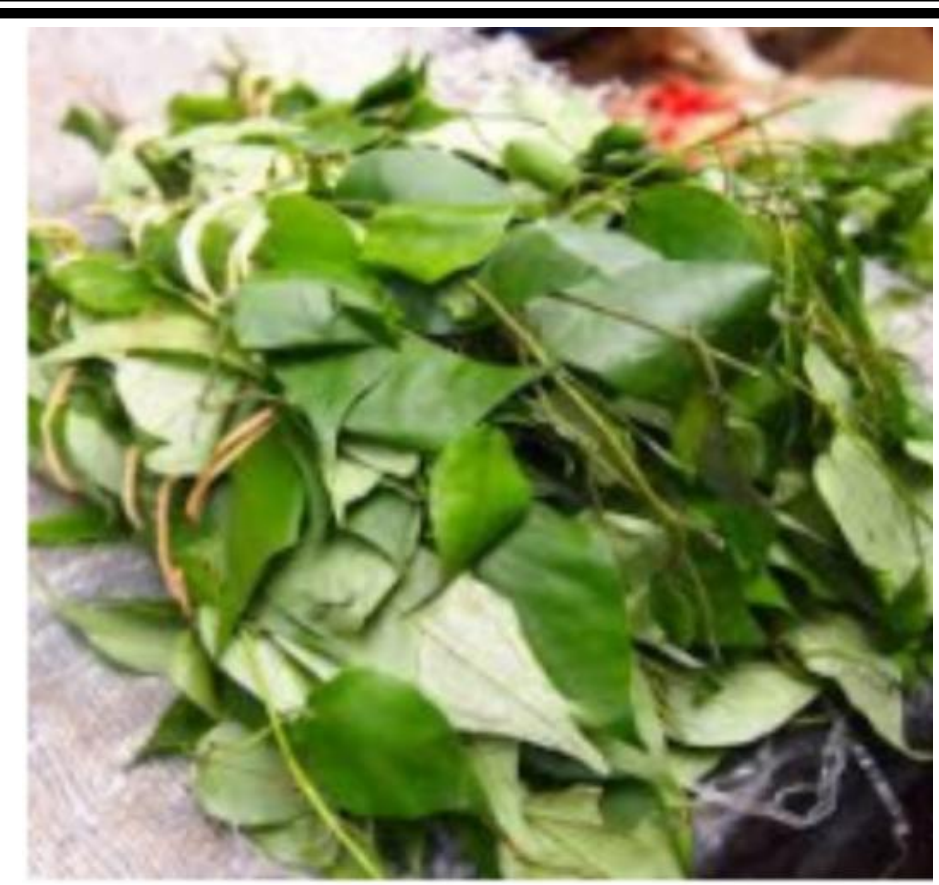

Plate 1: Leaves of Piper guineense

\section{Quantitative Determination of Phytochemicals}

\section{Tannins}

$25 \mathrm{ml}$ of $80 \%$ methanol was added to $0.50 \mathrm{~g}$ of the pre-treated sample, warmed for $30 \mathrm{~min}$ while the solution was filtered through Whatman \#1 filter paper, and diluted with $50 \mathrm{ml}$ of $80 \%$ methanol. $1 \mathrm{ml}$ of the extract was mixed with $0.6 \mathrm{ml}$ glacial acetic acid, $10 \mathrm{ml}$ pyridine $(20 \%)$ and $2.5 \mathrm{ml}$ aluminium chloride $(10 \%)$, and then diluted with $25 \mathrm{ml}$ distilled water. The mixture was allowed to stand for $30 \mathrm{~min}$ at $25^{\circ} \mathrm{C}$. Total tannins was determined by measurement of the absorbance at $420 \mathrm{~nm}$. A calibration standard (0.1- $0.5 \mathrm{mg} / \mathrm{L})$ prepared using tannic acid, was carried out through the procedure.

\section{Terpenes}

The total terpenoid content of the plant extracts was determined based on an assay using linalool as the standard for estimation. An aliquot of the reaction mixture obtained with Salkowski reagents was transferred to colorimetric cuvette. The absorbance was measured at $538 \mathrm{~nm}$ against a blank (95\% (v/v) methanol). For the standard calibration curve, $0.2 \mathrm{ml}$ of linalool solution in methanol was prepared and diluted to give a calibration standard in the range $0.2-1.0 \mathrm{mg} / \mathrm{L}$. Calibration curve of linalool was plotted and the total terpenoid contents expressed as milligrams of linalool equivalents per gram ( $\mathrm{mg}$ linalool/g) of plant material was determined using the regression equation of the calibration curve.

\section{Saponin}

The basic principle of this method is the reaction of oxidized saponin with vanillin. Sulfuric acid is used as oxidants and the distinctive color of this reaction is purple and is measured in $430 \mathrm{~nm} .0 .5 \mathrm{~g}$ of the homogenized plant material was extracted in $50 \mathrm{ml}$ of methanol by sonication, in an ultrasonic bath, for $30 \mathrm{~min}$. The crude extract was mixed with $1 \mathrm{ml}$ of vanillinsulfuric acid reagent, in a reaction vial. The vial was heated on a water bath at $60^{\circ} \mathrm{C}$ for $10 \mathrm{~min}$ 


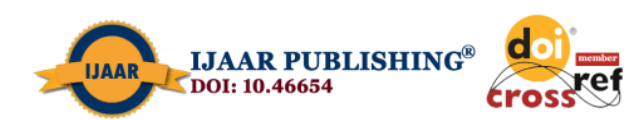

International Journal of Advanced Academic Research (Sciences, Technology and Engineering) | ISSN: 2488-9849

Journal DOI: 10.46654/ij.24889849

Vol. 6, Issue 8 (August, 2020) | www.ijaar.org

Article DOI: 10.46654/ij.24889849.e6813

to allow full color development. Thereafter, the mixture was cool for $10 \mathrm{~min}$ at room temperature before taking measurement at 430nm using a spectrophotometer. Diosgenin was used as calibration standard.

\section{Phenol}

$100 \mathrm{mg}$ each of the extract of the leaves was dissolved in $100 \mathrm{ml}$ of distilled water. Then $1 \mathrm{ml}$ of this solution was transferred to a test tube. Thereafter, $0.5 \mathrm{ml}$ of $2 \mathrm{~N}$ Folin- Ciocalteu reagent and $1.5 \mathrm{ml}$ of $20 \% \mathrm{Na} 2 \mathrm{CO} 3$ solution was added. The final volume was made up to $8 \mathrm{ml}$ with distilled water. The mixture was shaken vigorously, and then allowed to stand for 2 hours, at $25^{\circ} \mathrm{c}$. Thereafter, the absorbance was taken at $765 \mathrm{~nm}$. The data was use to estimate the total phenolic content using a calibration curve obtained from various diluted concentration of gallic acid.

\section{Alkaloids}

$2 \mathrm{~g}$ of extract residue was dissolved in $5 \mathrm{ml}$ of $2 \mathrm{M} \mathrm{HCl}$ and then filtered through Whatman \#1 filter paper. $1 \mathrm{ml}$ of the solution was transferred to a separating funnel and washed 3 times with $10 \mathrm{ml}$ portions of chloroform. The $\mathrm{pH}$ of this solution was adjusted to 7.0 , with $0.1 \mathrm{~N} \mathrm{NaOH}$, followed with addition of $5 \mathrm{ml}$ of BCG solution and $5 \mathrm{ml}$ of phosphate buffer solution. The extract was diluted to $10 \mathrm{ml}$ with chloroform, in a volumetric flask. Atropine $(0.25,0.50$ and 1.0 $\mathrm{mg} / \mathrm{ml}$ ) was used as standard for the calibration curve, and was carried through the above procedure. The absorbance of the complex in chloroform was measured at $470 \mathrm{~nm}$ with the spectrophotometer (Spectrumlab 352s), against the blank prepared as above but without Atropine.

\section{Flavonoid}

$0.5 \mathrm{~g}$ of the homogenized plant material was extracted in $50 \mathrm{ml}$ of methanol by sonication, in an ultrasonic bath, for $30 \mathrm{~min} .1 \mathrm{ml}$ of the extract in methanol was mixed with $1 \mathrm{ml}$ of methanol, 0.5 $\mathrm{ml}$ of $1.2 \%$ aluminium chloride solution, and $0.5 \mathrm{ml}$ potassium acetate $(120 \mathrm{~nm})$. The mixture was allowed to stand for $30 \mathrm{~min}$ at room temperature for color development. Thereafter, the absorbance was measured at $415 \mathrm{~nm}$.Quercetin was used as standard, and was carried through the procedure. The flavonoid content is expressed in terms of quercetin equivalent $(\mathrm{mg} / \mathrm{kg})$ of extracted compound.

\section{Qualitative Determination of Phytochemicals}

\section{Test for Phenol}

$5 \mathrm{ml}$ of the extract was pipetted into a $3 \mathrm{ml}$ test tube, then $10 \mathrm{ml}$ of distilled water was added. $2 \mathrm{ml}$ of ammonium hydroxide solution and $5 \mathrm{ml}$ of concentrated amyl alcohol were also added and left to react for 30mins. Development of bluish green color was taken as a positive presence of phenol.

\section{Test for Tannin}

$0.5 \mathrm{~g}$ of the sample was boiled in $20 \mathrm{ml}$ of water in a test tube and then filtered. A few drops of $0.1 \%$ ferric chloride was added and observed for brownish green or a blue-black coloration. 


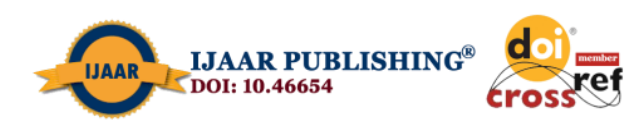

International Journal of Advanced Academic Research (Sciences, Technology and Engineering) | ISSN: 2488-9849

Journal DOI: 10.46654/ij.24889849

Vol. 6, Issue 8 (August, 2020) | www.ijaar.org

Article DOI: 10.46654/ij.24889849.e6813

\section{Test for Terpenes}

$5 \mathrm{ml}$ of each extract was mixed in $2 \mathrm{ml}$ of chloroform, followed by $3 \mathrm{ml}$ of concentrated $\mathrm{H}_{2} \mathrm{SO}_{4}$ to form a layer. A reddish brown coloration of the interface was formed to show positive results for the presence of terpenes.

\section{Test for Alkaloid}

A 5mg sample of the extract dissolved in $3 \mathrm{ml}$ of acidified ethanol was warmed slightly and then filtered. Few drops of Mayer reagent and $1 \mathrm{ml}$ of Dragendroff reagents were added to $1 \mathrm{ml}$ of the filtrate while turbidity was observed.

\section{Test for Saponin}

$2 \mathrm{~g}$ of the sample was boiled in $20 \mathrm{ml}$ of distilled water in a water bath and filtered. $10 \mathrm{ml}$ of the filtrate was mixed with $5 \mathrm{ml}$ of distilled water and shaken vigorously for a stable persistent froth. The frothing was mixed with 3 drops of olive oil and shaken vigorously until the formation of emulsion is observed.

\section{Test for Flavonoid}

$5 \mathrm{ml}$ of dilute ammonia solution were added to a portion of the aqueous filtrate of each plant extract followed by addition of concentrated $\mathrm{H}_{2} \mathrm{SO}_{4}$.

\section{Digestion and Measurement of Heavy metal (Cd, $\mathrm{Cu}, \mathrm{Cr}, \mathrm{Pb}, \mathrm{Zn}, \mathrm{As}, \mathrm{Ni})$}

Heavy metals were digested and measured following the method described by Adu et al. (2020).

\section{Statistical Analysis}

Data were computed using statistical package for social sciences (SPSS, version 20). The differences in the means were tested using one-way analysis of variance (ANOVA) while the significant level was calculated as $\mathrm{p}<0.05$.

\section{RESULTS}

The qualitative results of the phytochemicals of Piper guineense(dry and wet samples) from Igando, Ikotun and Egbeda markets in Lagos, Nigeria, revealed the presence of Alkaloids, Tannins, Flavonoids, Terpenes, Saponins and Phenols. While Table I showed the quantitative phytochemicals of $P$. guineense, the concentration of heavy metals (dry and wet sample) in $P$. guineense from the three markets are presented in Table II. On the other hand, the World Health Organization (WHO) heavy metal's recommended limits for cultivated plants and soil is shown in Table III.

The amount of alkaloids in the dry samples from the three markets ranged from $40.43 \pm 18.08$ $53.12 \pm 0.14 \mathrm{mg} / 100 \mathrm{~g}$ and the wet samples $(29.87 \pm 0.02-37.66 \pm 0.00 \mathrm{mg} / 100 \mathrm{~g}$ ). Alkaloids (dry and wet weight) in $P$. guineense gotten from Igando market was significantly $(p<0.05)$ higher than the values recorded from other markets. The concentrations of tannins in the dry samples from the three markets ranged from $4.44 \pm 0.01-9.06 \pm 4.17 \mathrm{mg} / 100 \mathrm{~g}$ while the wet samples varied from $2.97 \pm 0.02$ to $4.12 \pm 0.00 \mathrm{mg} / 100 \mathrm{~g}$. The highest tannins recorded in P. guineense was gotten from Egbeda market in comparison with that from Ikotun and Igando.

Flavonoids contents in the dry samples from Igando, Ikotun and Egbeda markets ranged from $49.77 \pm 25.60-67.99 \pm 0.17 \mathrm{mg} / 100 \mathrm{~g}$, while $12.65 \pm 0.01-23.98 \pm 0.00 \mathrm{mg} / 100 \mathrm{~g}$ was recorded in the wet samples. The contents of Flavonoids in $P$. guineense from Igando market was 
International Journal of Advanced Academic Research (Sciences, Technology and Engineering) | ISSN: 2488-9849

Journal DOI: 10.46654/ij.24889849

Vol. 6, Issue 8 (August, 2020)|www.ijaar.org

Article DOI: 10.46654/ij.24889849.e6813

significantly higher than flavonoids obtained in other markets. The quantity of terpenes in the dry samples from the three markets ranged from $6.98 \pm 0.00-14.63 \pm 0.18 \mathrm{mg} / 100 \mathrm{~g}$ while in the wet samples, $4.96 \pm 0.02-8.95 \pm 0.00 \mathrm{mg} / 100 \mathrm{~g}$ was obtained. Terpenes in Piper guineense gotten from Igando market was the highest among the markets. The amount of saponins in the dry and wet samples respectively were $2.67 \pm 0.00-5.99 \pm 0.14 \mathrm{mg} / 100 \mathrm{~g}$ and $2.02 \pm 0.01-4.76 \pm 0.00$ $\mathrm{mg} / 100 \mathrm{~g}$. The amount of phenols in the dry samples ranged from $4.55 \pm 0.00$ to $6.02 \pm 0.11$ $\mathrm{mg} / 100 \mathrm{~g}$ while in the wet samples, the values are $1.88 \pm 0.02$ to $3.45 \pm 0.02 \mathrm{mg} / \mathrm{kg}$. Samples from Igando market had the peak saponin and phenol contents.

Table I: Phytochemicals (dry and wet Samples) of Piper guineense from three markets in Lagos, Nigeria

\begin{tabular}{|c|c|c|c|c|c|c|}
\hline \multicolumn{7}{|c|}{ Locations } \\
\hline \multicolumn{3}{|c|}{ Igando } & \multicolumn{2}{|c|}{ Ikotun } & \multicolumn{2}{|l|}{ Egbeda } \\
\hline & Dry weight & Wet weight & Dry weight & Wet weight & Dry weight & Wet weight \\
\hline Alkaloids & $53.12 \pm 0.1^{\mathrm{ab}}$ & $37.66 \pm 0.00^{\mathrm{a}}$ & $49.88 \pm 0.00^{b}$ & $29.87 \pm 0.02^{\text {bb }}$ & $40.43 \pm 18.08^{b c}$ & $33.21 \pm 0.01^{\mathrm{c}}$ \\
\hline Tannins & $6.21 \pm 0.13^{\mathrm{a}}$ & $4.12 \pm 0.00^{b}$ & $4.44 \pm 0.01^{b}$ & $2.97 \pm 0.02^{\mathrm{aa}}$ & $9.06 \pm 4.17^{\mathrm{c}}$ & $4.08 \pm 0.00^{b}$ \\
\hline Flavonoids & $67.99 \pm 0.17^{\mathrm{a}}$ & $23.98 \pm 0.00^{\mathrm{bb}}$ & $58.87 \pm 35.3^{b}$ & $12.65 \pm 0.01^{\mathrm{ab}}$ & $49.77 \pm 25.60^{b c}$ & $23.88 \pm 0.00^{\mathrm{c}}$ \\
\hline Terpenes & $14.63 \pm 0.18^{\mathrm{a}}$ & $8.95 \pm 0.00^{\mathrm{ab}}$ & $6.98 \pm 0.00^{\mathrm{bb}}$ & $4.96 \pm 0.02^{b}$ & $8.86 \pm 8.34^{\mathrm{ac}}$ & $6.16 \pm 0.01^{b}$ \\
\hline Saponins & $5.99 \pm 0.14^{\mathrm{a}}$ & $4.76 \pm 0.00^{\mathrm{aa}}$ & $2.67 \pm 0.00^{b}$ & $2.02 \pm 0.01^{\mathrm{ab}}$ & $3.11 \pm 3.94^{b}$ & $2.14 \pm 0.00^{\mathrm{ab}}$ \\
\hline Phenols & $6.02 \pm 0.11^{\mathrm{a}}$ & $2.97 \pm 0.00^{\mathrm{aa}}$ & $4.55 \pm 0.00^{b}$ & $1.88 \pm 0.02^{\mathrm{ab}}$ & $5.13 \pm 1.37^{b}$ & $3.45 \pm 0.02^{\mathrm{ab}}$ \\
\hline
\end{tabular}

Mean \pm SD $(\mathrm{mg} / 100 \mathrm{~g})$ with difference superscript in the row = significant different $(\mathrm{p}<0.05)$

As presented in Table II, the level of metals $(\mathrm{mg} / \mathrm{kg})$ are as follows: Arsenic in Piper guineense (dry and wet) from Igando, Ikotun and Egbeda markets respectively are: $(0.05 \pm 0.01$ and $0.04 \pm 0.02),(0.05 \pm 0.03$ and $0.04 \pm 0.01)$ and $(0.05 \pm 0.07$ and $0.05 \pm 0.02)$. The content of Cadmium in $P$. guineense (dry and wet weight) from Igando, Ikotun and Egbeda was $(0.05 \pm 0.04$ and $0.04 \pm 0.00),(0.05 \pm 0.03$ and $0.04 \pm 0.01)$ and $(0.04 \pm 0.02$ and $0.03 \pm 0.02)$ respectively. Copper content in P.guineense (dry and wet) from Igando, Ikotun and Egbeda was $(0.05 \pm 0.01$ and $0.04 \pm 0.02),(0.05 \pm 0.03$ and $0.04 \pm 0.01)$ and $(0.05 \pm 0.07$ and $0.05 \pm 0.02)$ respectively. The amount of chromium in $P$. guineense (dry to wet) from Igando, Ikotun and Egbeda was $(0.04 \pm 0.01,0.04 \pm 0.02),(0.05 \pm 0.01,0.03 \pm 0.00)$ and $(0.04 \pm 0.01,0.02 \pm 0.02)$ respectively. Lead concentration in P. guineense (dry to wet) from Igando, Ikotun and Egbeda was $(0.03 \pm 0.00,0.03 \pm 0.03),(0.04 \pm 0.00,0.02 \pm 0.03)$ and $(0.05 \pm 0.01,0.04 \pm 0.03)$ respectively. The amount of nickel in $P$. guineense (dry and wet weight) from Igando, Ikotun and Egbeda was $(0.05 \pm 0.01,0.02 \pm 0.01),(0.05 \pm 0.00,0.03 \pm 0.01)$ and $(0.05 \pm 0.01,0.05 \pm 0.02)$ respectively. The amount of zinc in $P$. guineense (dry and wet weight) from Igando, Ikotun and Egbeda respectively was $(0.37 \pm 0.02,0.26 \pm 0.00),(0.29 \pm 0.00,0.14 \pm 0.00)$ and $(0.31 \pm 0.10,0.19 \pm 0.00)$. There was no significant difference $(\mathrm{p}>0.05)$ in contents of all heavy metals detected in $P$. guineense across the three markets. 
International Journal of Advanced Academic Research (Sciences, Technology and Engineering) | ISSN: 2488-9849

Journal DOI: 10.46654/ij.24889849

Vol. 6, Issue 8 (August, 2020) | www.ijaar.org

Article DOI: 10.46654/ij.24889849.e6813

Table II: Heavy metals in Piper guineense (Dry and wet weight) from three markets in Lagos, Nigeria

\begin{tabular}{|c|c|c|c|c|c|c|}
\hline & \multicolumn{6}{|c|}{ Locations } \\
\hline & \multicolumn{2}{|c|}{ Igando } & \multicolumn{2}{|c|}{ Ikotun } & \multicolumn{2}{|c|}{ Egbeda } \\
\hline & Dry weight & Wet weight & $\begin{array}{c}\text { Dry } \\
\text { weight }\end{array}$ & Wet weight & Dry weight & $\begin{array}{l}\text { Wet } \\
\text { weight }\end{array}$ \\
\hline Arsenic & $\begin{array}{l}0.05 \pm \\
0.01^{\mathrm{a}}\end{array}$ & $\begin{array}{l}0.04 \pm \\
0.02^{\mathrm{a}}\end{array}$ & $\begin{array}{l}0.05 \pm \\
0.03^{\mathrm{a}}\end{array}$ & $\begin{array}{l}0.04 \pm \\
0.01^{\mathrm{a}}\end{array}$ & $\begin{array}{l}0.05 \pm \\
0.07^{\mathrm{a}}\end{array}$ & $\begin{array}{l}0.05 \pm \\
0.02^{\mathrm{a}}\end{array}$ \\
\hline Cadmium & $\begin{array}{l}0.05 \pm \\
0.04^{\mathrm{a}}\end{array}$ & $\begin{array}{l}0.04 \pm \\
0.00^{\mathrm{a}}\end{array}$ & $\begin{array}{l}0.05 \pm \\
0.01^{\mathrm{a}}\end{array}$ & $\begin{array}{l}0.04 \pm \\
0.01^{\mathrm{a}} \\
\end{array}$ & $\begin{array}{l}0.04 \pm \\
0.02^{\mathrm{a}}\end{array}$ & $\begin{array}{l}0.03 \pm \\
0.02^{\mathrm{a}}\end{array}$ \\
\hline Copper & $\begin{array}{l}0.12 \pm \\
0.00^{\mathrm{a}}\end{array}$ & $\begin{array}{l}0.08 \pm \\
0.00^{\mathrm{a}}\end{array}$ & $\begin{array}{l}0.19 \pm \\
0.00^{\mathrm{a}}\end{array}$ & $\begin{array}{l}0.10 \pm \\
0.00^{\mathrm{a}}\end{array}$ & $\begin{array}{l}0.08 \pm \\
0.06^{\mathrm{a}}\end{array}$ & $\begin{array}{l}0.04 \pm \\
0.00^{\mathrm{a}}\end{array}$ \\
\hline Chromium & $\begin{array}{l}0.04 \pm \\
0.01^{\mathrm{a}}\end{array}$ & $\begin{array}{l}0.04 \pm \\
0.02^{\mathrm{a}}\end{array}$ & $\begin{array}{l}0.05 \pm \\
0.01^{\mathrm{a}}\end{array}$ & $\begin{array}{l}0.03 \pm \\
0.00^{\mathrm{a}}\end{array}$ & $\begin{array}{l}0.04 \pm \\
0.01^{\mathrm{a}}\end{array}$ & $\begin{array}{l}0.02 \pm \\
0.02^{\mathrm{a}}\end{array}$ \\
\hline Lead & $\begin{array}{l}0.03 \pm \\
0.00^{\mathrm{a}}\end{array}$ & $\begin{array}{l}0.03 \pm \\
0.03^{\mathrm{a}} \\
\end{array}$ & $\begin{array}{l}0.04 \pm \\
0.00^{\mathrm{a}} \\
\end{array}$ & $\begin{array}{l}0.02 \pm \\
0.03^{\mathrm{a}} \\
\end{array}$ & $\begin{array}{l}0.05 \pm \\
0.01^{\mathrm{a}} \\
\end{array}$ & $\begin{array}{l}0.04 \pm \\
0.03^{\mathrm{a}} \\
\end{array}$ \\
\hline Nickel & $\begin{array}{l}0.05 \pm \\
0.01^{\mathrm{a}}\end{array}$ & $\begin{array}{l}0.02 \pm \\
0.01^{\mathrm{a}}\end{array}$ & $\begin{array}{l}0.05 \pm \\
0.00^{\mathrm{a}}\end{array}$ & $\begin{array}{l}0.03 \pm \\
0.01^{\mathrm{a}}\end{array}$ & $\begin{array}{l}0.05 \pm \\
0.03^{\mathrm{a}}\end{array}$ & $\begin{array}{l}0.05 \pm \\
0.03^{\mathrm{a}}\end{array}$ \\
\hline Zinc & $\begin{array}{l}0.37 \pm \\
0.02^{\mathrm{a}}\end{array}$ & $\begin{array}{l}0.26 \pm \\
0.00^{\mathrm{a}}\end{array}$ & $\begin{array}{l}0.29 \pm \\
0.00^{\mathrm{a}}\end{array}$ & $\begin{array}{l}0.14 \pm \\
0.00^{\mathrm{a}}\end{array}$ & $\begin{array}{l}0.19 \pm \\
0.00^{\mathrm{a}}\end{array}$ & $\begin{array}{l}0.19 \pm \\
0.00^{\mathrm{a}}\end{array}$ \\
\hline
\end{tabular}

Mean $\pm \mathrm{SD}(\mathrm{mg} / \mathrm{kg})$ with difference superscript in the row $=$ significant different $(\mathrm{p}<0.05)$

Table III: WHO permissible limits for heavy metals in plants and soil

\begin{tabular}{|l|l|l|}
\hline Elements & Targets value of soil $(\mathrm{mg} / \mathrm{kg})$ & Permissible value of plant $(\mathrm{mg} / \mathrm{kg})$ \\
\hline $\mathrm{Cd}$ & 0.8 & 0.002 \\
\hline $\mathrm{Zn}$ & 50 & 0.60 \\
\hline $\mathrm{Cu}$ & 36 & 10 \\
\hline $\mathrm{Cr}$ & 100 & 1.30 \\
\hline $\mathrm{Pb}$ & 85 & 2 \\
\hline $\mathrm{Ni}$ & 35 & 10 \\
\hline
\end{tabular}

Target values are specified to indicate desirable maximum levels of elements in unpolluted soils Source: WHO (1996)

The frequency distributions of the phytochemicals in $P$. guineense for dry and wet weight respectively are shown in Figure 1 and 2. For the leaf dry weight, most frequent and least phytochemicals respectively across the markets are: flavonoid and saponin(Igando market), alkaloid and saponin (Ikotun market) and flavonoid and saponin(Egbeda), while for the wet weight, the most frequent and least phytochemicals are: alkaloid and phenol (Igando market), alkaloid and phenol(Ikotun market), alkaloid and saponin (Egbeda market) . 


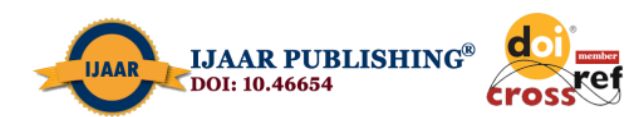

International Journal of Advanced Academic Research (Sciences, Technology and Engineering) | ISSN: 2488-9849 Vol. 6, Issue 8 (August, 2020)| www.ijaar.org

Journal DOI: 10.46654/ij.24889849

Article DOI: 10.46654/ij.24889849.e6813

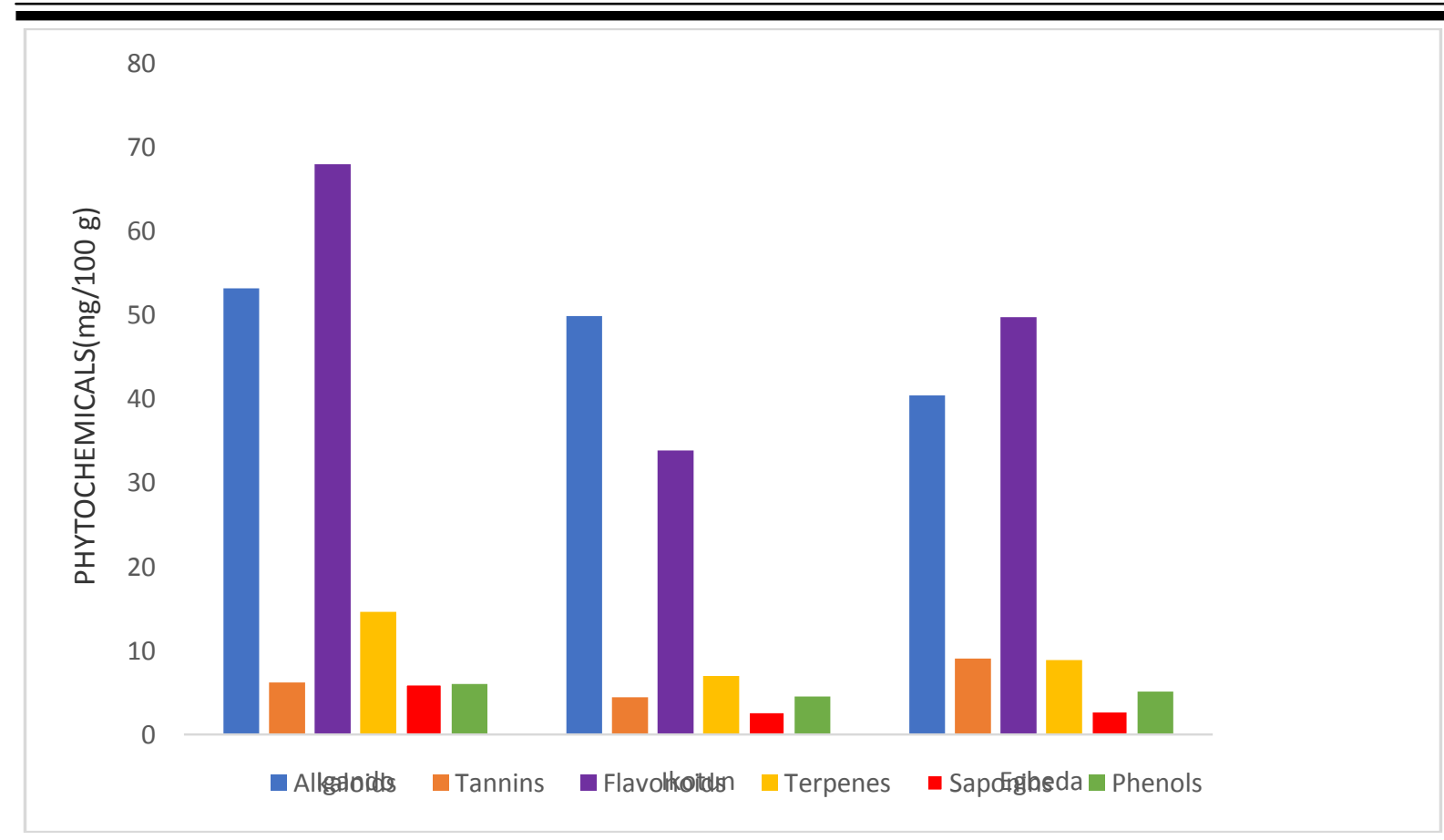

Figure 1: Dry Weight of phytochemical compound in $P$. guineense leaves

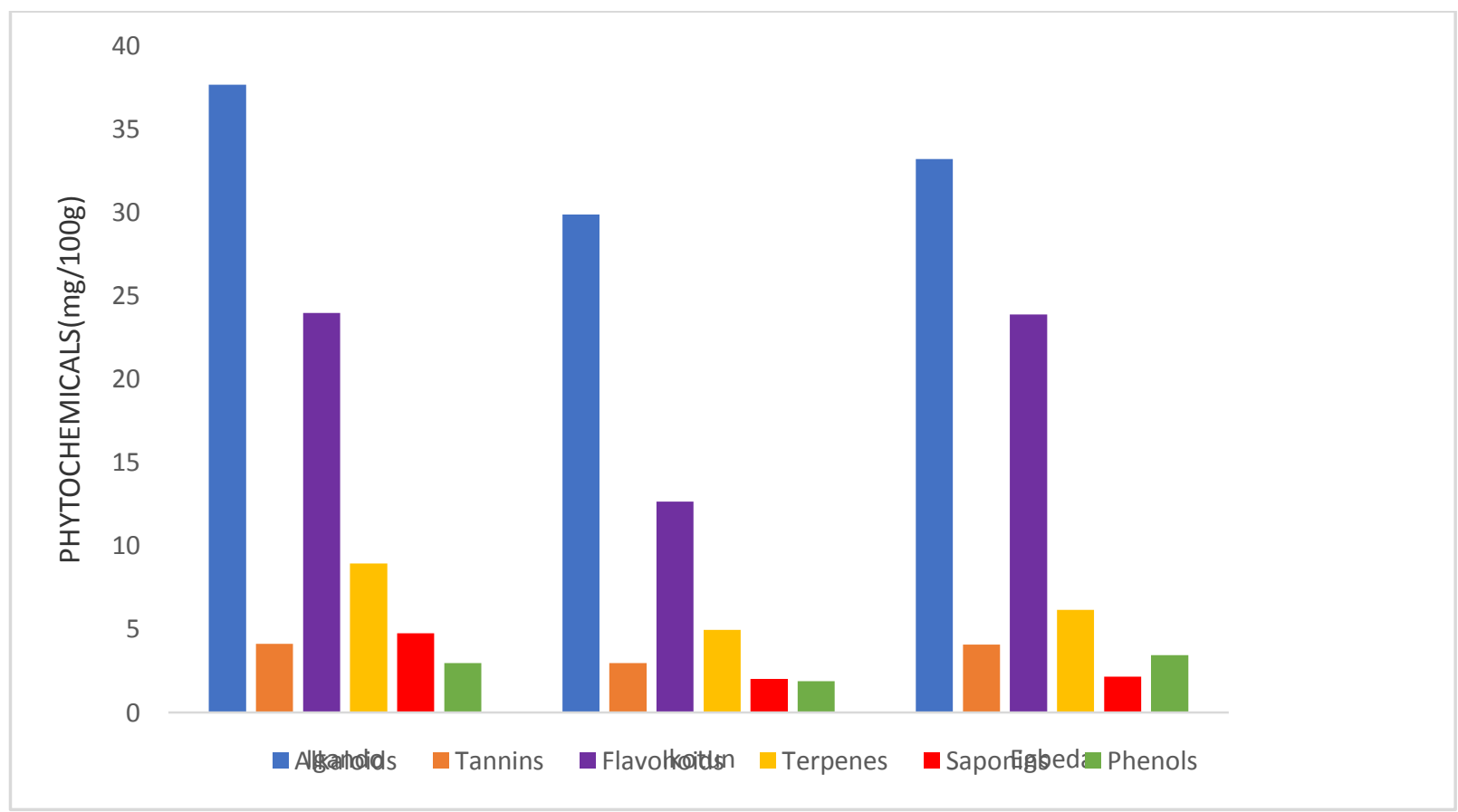

Figure 2: Wet Weight of phytochemical compound in $P$. guineense leaves

On the other hand, the frequency distributions of heavy metals in P. guineense for dry and wet weight respectively are shown in Figure 3 and 4. For the dry weight, most frequent and least metals respectively are: Igando market (zinc and lead), Ikotun market (zinc and lead) and Egbeda market (copper and cadmium) while for the wet weight, the highest and least heavy metals are: Igando (zinc and nickel), Ikotun (zinc and lead) and Egbeda (zinc and chromium) . 


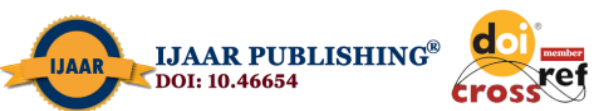

International Journal of Advanced Academic Research (Sciences, Technology and Engineering) | ISSN: 2488-9849 Vol. 6, Issue 8 (August, 2020) | www.ijaar.org

Journal DOI: 10.46654/ij.24889849

Article DOI: 10.46654/ij.24889849.e6813

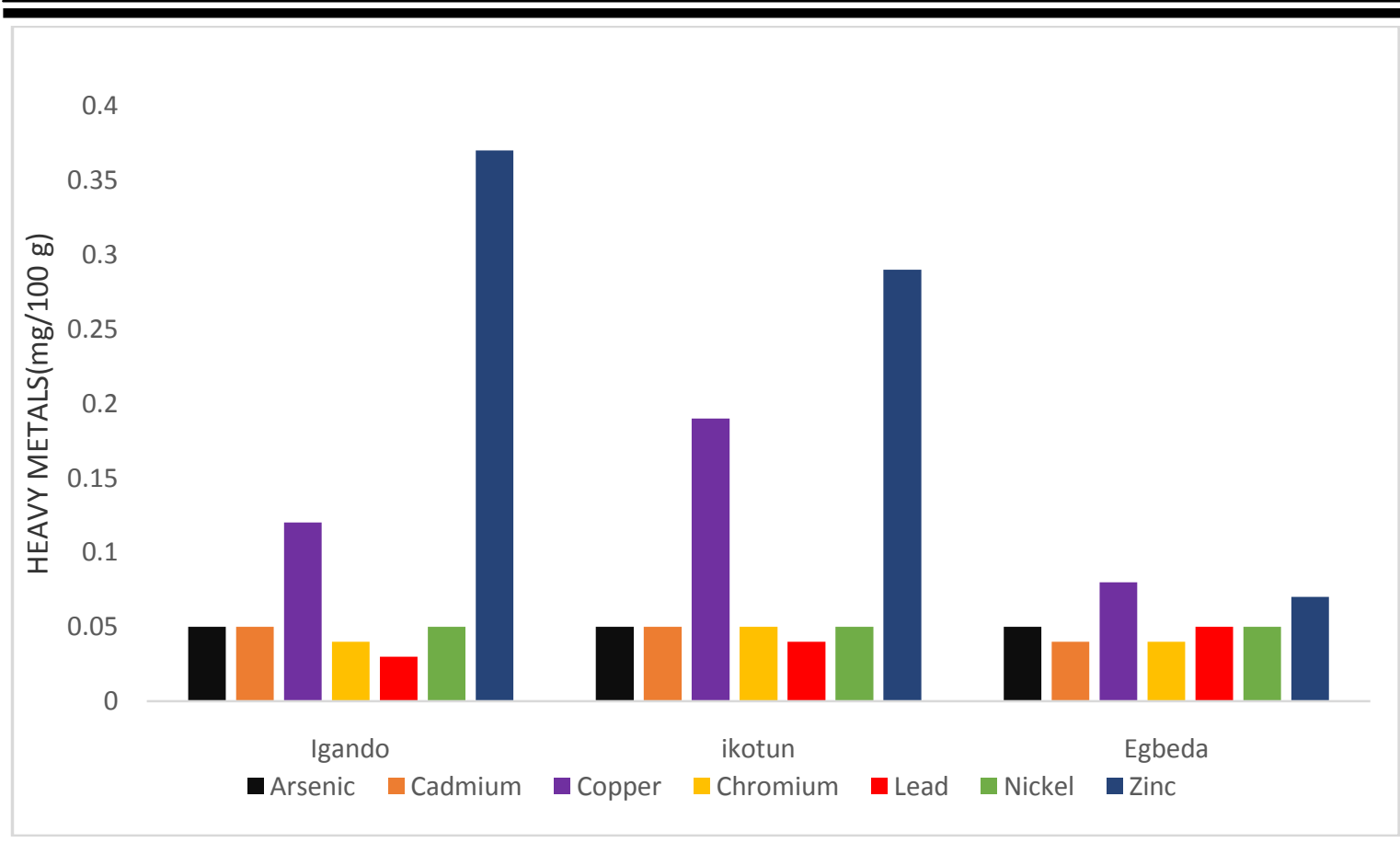

Figure 3: Dry Weight of heavy metals composition in Piper guineense leaves

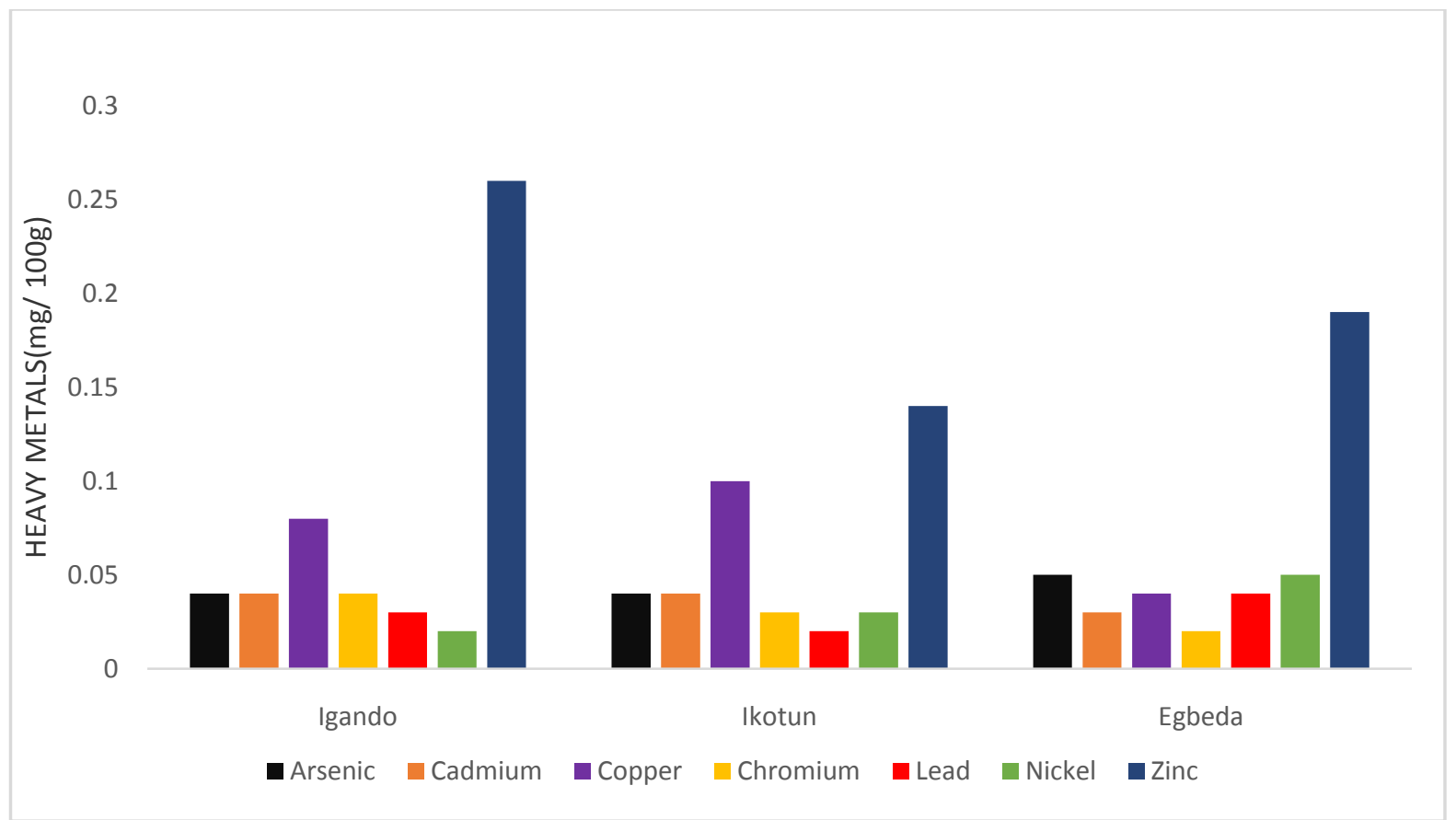

Fig 4: Wet Weight of heavy metal composition in wet Piper guineense leaves

\section{Discussion}

Phytochemical analysis is very useful in the evaluation of some active biological components of some vegetables. The phytochemical composition of Piper guineense (Uziza leave) recorded in this study which revealed the presence of alkaloids, tannins, saponins, flavonoids, terpene, and phenols was similar to that examined at Osaa-Oke in Obingwa L.G.A, Aba, Abia State (Chiwendu et al., 2016). Dibolu et al.(2017) reported that leaf extracts of $P$. guineense has 


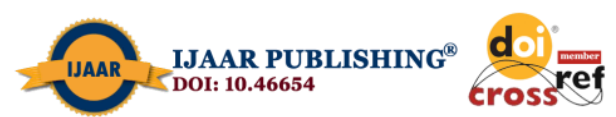

International Journal of Advanced Academic Research (Sciences, Technology and Engineering) | ISSN: 2488-9849

Journal DOI: 10.46654/ij.24889849

Vol. 6, Issue 8 (August, 2020)| www.ijaar.org

Article DOI: 10.46654/ij.24889849.e6813

strong or intense positivity for alkaloids, moderate positivity for flavonoids, steroids, tannins, terpenoids, cardiac glycosides and total phenols, and weak positivity for saponins. On the other hand, Besong et al. (2016) reported that P. guineense contains Alkaloids (piperine, wisamine, dihydrowasamine, dihydropiperine), flavonoids, saponins, tannins, resins and essential oil (dillapiole, elemicin, cardiac glycosides).

In this study, the dry samples showed higher level of bioactive compounds than the wet samples. The reason may be that the bioactive compounds are not volatile compounds and hence have a high dried weight. This result is in correlation with the findings of Aja et al.,(2010). High level of flavonoids which ranged from $67.99 \pm 0.17 \mathrm{mg} / 100 \mathrm{~g}$ in the examined dry samples to $12.65 \pm 0.1 \mathrm{mg} / 100 \mathrm{~g}$ in the wet samples implied that $P$. guineense is good in the control of inflammation and cancer prevention as opined by Winkel-shirley (2001). Flavonoids may help provide protection against this disease by contributing along with antioxidants vitamins and enzymes, to the total antioxidant defense system to the human body. The results of the present study also showed low level of tannins, saponins and phenols. Since, the values are low, it could indicate that these phytochemicals found in $P$. guineense are not high enough to constitute human poison. Similar low concentrations of phytochemicals have been reported by Chinwendu et al. (2016).

Heavy metal is not toxic per se but become toxic only when its concentration in the plant and animal exceeds a certain threshold, that is the dose makes the poison. Heavy metals are significant environmental pollutants and their toxicity is a problem of increasing significance for ecological, evolutionary, nutritional and environmental reasons (Jaishankar et al., 2014). The level of cadmium reported in $P$. guineense in this study from the three markets was not higher than the maximum permissible limit $(0.002 \mathrm{mg} / \mathrm{kg})$ recommended by World Health Organization (WHO). Similarly, the concentration of zinc and copper were lower than the standard permissible limit of $10 \mathrm{mg} / \mathrm{kg}$. The levels of arsenic, chromium, lead and nickel in $P$. guineense from the three markets are all lower than the permissible limit recommended by WHO as shown in Table 3.

\section{Conclusion}

The study has shown that Piper guineense is a potential nutritive and medicinal vegetable. The phytochemical analysis of $P$. guineense serves as a good complement for food and also contains some considerable amount of anti-oxidant such as alkaloid, flavonoids and terpenes which could contribute some health benefit to its consumers. $P$. guineense from Igando had the highest alkaloids, flavonoids, saponins, terpenes and phenol; while the highest tannin content was found in $P$. guineense from Egbeda. All the metals in the $P$. guineense were below WHO maximum permissible limit. The findings therefore indicated that $P$. guineense collected from the markets are safe for consumption and good for medicinal use. 
International Journal of Advanced Academic Research (Sciences, Technology and Engineering) | ISSN: 2488-9849

Journal DOI: 10.46654/ij.24889849 Vol. 6, Issue 8 (August, 2020) | www.ijaar.org

Article DOI: 10.46654/ij.24889849.e6813

\section{Reference}

Adeyolanu, O.D., Kadiri, O. J., Are, K. S., and Oluwatosin, G. A. (2016). Lead and cadmium contents in a medicinal plant/spice grown in an urban city of Nigeria. Cogent Food and Agriculture, 2(1). https://doi.org/10.1080/23311932.2015.1136016

Adu, A.A., Aderinola, O.J., Mekuleyi, G.O. and Adebayo, P.O.(2020). Comparative Assessment of Heavy Metals Concentration in Leaf, Stem and Root of Water Leaf (Talinum triangulare) (Jacq Willd, 1799) Grown on the Soil of Cassidy's Dumpsite and Farmland in Ojo, Lagos State. Journal of Medicinal Plants Studies, 8(3):80-83.

Aja, P.M., Okaka, A.N., Onu, P.N., Ibiam, U., and Urako, A. J.(2010). Pakistan Journal of Nutrition. Phytochemical Composition of Talinum Triangulare (Water Leaf) Leaves, 9(6), 527-529.

Asgarpanah, J. and Haghight, E.(2012). Phytochemistry and pharmacologic properties of Ziziphus spina christi (L.) Willd. African Journal of Pharmacy and Pharmacology, 6(31). https://doi.org/10.5897/ajpp12.509

Bennerman, R.B. and chen, J.W (1983) Medicinal plants and primary health care: an agenda for action Traditional Medicine and Health Care CoverageWorld Health Organization Geneva, Switzerland.

Besong, E., Balogun, E., Djobissie, F. A., Ogochukwu, S., and Obimma, J. (2016).A Review of Piper guineense (African Black Pepper). International Journal of Pharmacy And Pharmaceutical Research , 6(1), 371-372.

Chinwendu, S., Ejike, E. N., Ejike, B. U., Oti, W. and Nwachukwu, I.(2016). Phytochemical Properties Of Uziza Leave (Piper Guineense). European Journal of Pure and Applied Chemistry, 3(2), 12-13.

Dibulo, C. C., Madu, K. C., Ogbu, P. N., Onyeachu, B. I., and Njoku, D. I. (2017).Proximate and Phytochemical Analysis of Ethanolic Extract of Leaves of Piper guineense from South eastern Nigeria. IOSR Journal of Applied Chemistry , 10(8), 46-48.

Dwivedi, S. K., and Dey, S. (2002). Medicinal Herbs: A Potential Source of Toxic Metal Exposure for Man and Animals in India. Archives of Environmental Health: An International Journal, 57(3), 229-231. https://doi.org/10.1080/00039890209602941

Harborne, J. B. (1999). Chemicals from Plants: Perspectives on Plant Secondary Products [Google books]. In N. Waton and D. Brown (Eds.), Classes and functions of secondary products from plant (pp. 3-13). London: Imperial college press.

Jaishankar, M., Mathew, B.B., Shah, M.S. and Gowda, K.R.S. (2014). Biosorption of Few Heavy Metal Ions Using Agricultural Wastes. Journal of Environment Pollution and Human Health, 2(1):1-6.

Ruffo , C., Birnie, A., and Tengnas, B. (2002). Edible wild plants of Tanzania. Retrieved December 20, 2019, from http://www.worldagroforestry.org/publication/edible-wildplants-tanzania 


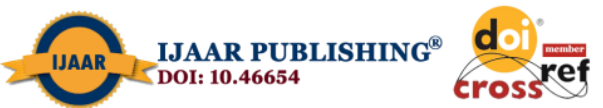

International Journal of Advanced Academic Research (Sciences, Technology and Engineering) | ISSN: 2488-9849

Journal DOI: 10.46654/ij.24889849 Vol. 6, Issue 8 (August, 2020)|www.ijaar.org

Article DOI: 10.46654/ij.24889849.e6813

WHO (1996) Permissible limits of heavy metals in soil and plants (Geneva: World Health Organization), Switzerland.

Winkel-Shirley, B. (2001). Flavonoid Biosynthesis. A Colorful Model for Genetics, Biochemistry, Cell Biology, and Biotechnology. Plant Physiology, 126(2), 485-493. https://doi.org/10.1104/pp.126.2.485 